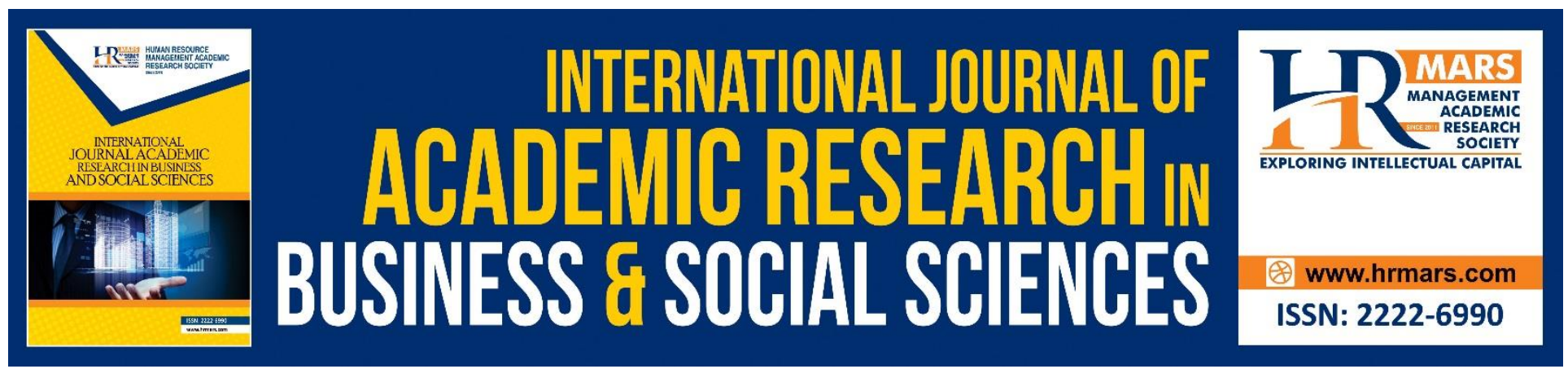

\title{
Muslim Friendly Tourism: Concept, Practices and Challenges in Malaysia
}

\section{Azreen Hamiza Binti Abdul Aziz}

To Link this Article: http://dx.doi.org/10.6007/IJARBSS/v8-i11/4908

DOI: $10.6007 /$ IJARBSS/v8-i11/4908

Received: 16 Oct 2018, Revised: 09 Nov 2018, Accepted: 25 Nov 2018

Published Online: 27 Nov 2018

In-Text Citation: (Aziz, 2018)

To Cite this Article: Aziz, A. H. B. A. (2018). Muslim Friendly Tourism: Concept, Practices and Challenges in Malaysia. International Journal of Academic Research in Business and Social Sciences, 8(11), 355-363.

\section{Copyright: (c) 2018 The Author(s)}

Published by Human Resource Management Academic Research Society (www.hrmars.com)

This article is published under the Creative Commons Attribution (CC BY 4.0) license. Anyone may reproduce, distribute, translate and create derivative works of this article (for both commercial and non-commercial purposes), subject to full attribution to the original publication and authors. The full terms of this license may be seen

at: http://creativecommons.org/licences/by/4.0/legalcode

Vol. 8, No. 11, 2018, Pg. 355 - 363

http://hrmars.com/index.php/pages/detail/IJARBSS

JOURNAL HOMEPAGE

Full Terms \& Conditions of access and use can be found at http://hrmars.com/index.php/pages/detail/publication-ethics 


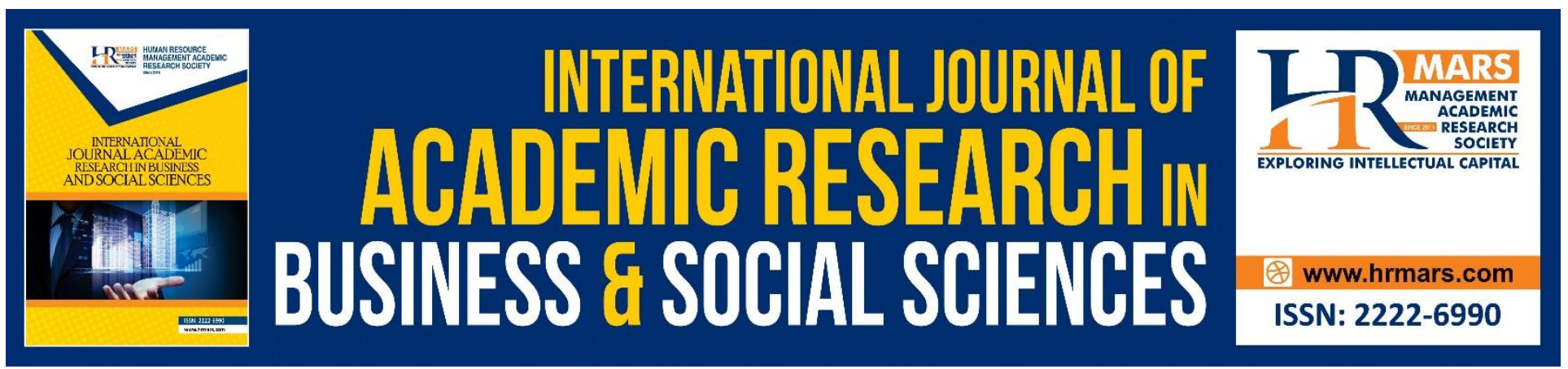

\title{
Muslim Friendly Tourism: Concept, Practices and Challenges in Malaysia
}

\author{
Azreen Hamiza Binti Abdul Aziz \\ Centre for Islamic Development Management Studies (ISDEV), Universiti Sains Malaysia, Malaysia \\ Email: azreenhamiza@usm.my
}

\begin{abstract}
The emergence of Muslim Friendly Tourism (MFT) in the industry and research has become a regional phenomenon with the awareness among Muslims that are preferring the MFT travel option has increased over time. MFT has penetrate a large share of Muslim in MFT as stated in the global economic report 2017 with the size of global Islamic Economy Sector is at USD 169 billion. Malaysia led most of the main interactions in MFT that offer Muslim travelers a safer and comfort travelling option. Therefore, the success of Malaysia's concept, practices and challenges in developing and promoting MFT need to be identify in order to nurture the contemporary tourism practices. This paper intends to explore the concept, practices and challenges of MFT in Malaysia along with the examples of its current best practices. An interpretive explanatory research design is used with secondary data through document research as the main data collection method. The analysis of the data is done by using the qualitative content analysis method. The findings found that the concept of MFT still developing and both practices and challenges are in the process of evolving the tourism industry.
\end{abstract}

Keywords: Muslim friendly tourism (MFT), Tourism and Hospitality, Malaysia

\section{Introduction}

Tourism industry is one of the largest and fastest economic sectors that received an overwhelming support throughout the world. Over the past decade, Islamic tourism industry shows a positive growth and continue to be one of the top contributors in the service sector to the national economy. According to the Global Islamic Economy (GIE) Report 2017/2018, travelling has been the latest development and trends that boost up the Islamic tourism industry. The report shows that the number of Muslims spend on travel was at approximately RM659 billion in 2016 and is expected to reach RM1103 billion by 2022 (GIE report 2017). The tourism industry is quickly moving out of its niche status especially in Islamic tourism or as known as Muslim friendly tourism (MFT) field. Most of companies, hoteliers, restaurateurs, tour operators as well as travellers continue to open and make their presence in the services sector. 
Looking at the Muslim tourist' contribution to the global tourism economy, the global spending of Muslim tourist in 2016 is RM727 billion which is $11.9 \%$ of the global expenditure (excluding hajj/umrah). The data estimated to increase by $40 \%$ billion in 2022 (The Global Islamic Economy Report, 2018). In Malaysia, the performance of its tourism industry is based on the international tourist arrival and the international tourism receipts. Based on the halal travel indicator, Malaysia rank second place next to the United Arab Emirates (UAE) for countries that have the best developed ecosystem for Muslim Friendly Tourism. Malaysia has the potential especially in the transportation infrastructure, accommodation infrastructure and hospitality suppliers, food and beverages, travel agencies, as well as entertainment and attraction infrastructure. Since then, there has been an increasing focus on the tourism industry products and services especially in promoting Muslimfriendly tourism. Generally, this study aims to overview the current concept of MFT and to highlight the practices and challenges MFT would be facing in striving to achieve a better growth of the economy in the near future.

\section{Methods}

This study is a qualitative research method with interpretive exploratory research design. Secondary data from two main sources are collected. First is from the primary source of al-Qur'an and Hadith and second is from the secondary source is collected from literature, reports and documents that are related to hospitality. Based on the eccentric figure and report findings, the untapped market in the Muslim population is very significant to uncover in order to maximize the economics benefits and to maintain the sustainability of the tourism industry. Thus, in the first section of this paper intended to grasp the overview of the MFT concept. Second, reveal the practice of MFT in Malaysia and then explored the challenges in achieving the success of the MFT industry. The study also adds to the literature of MFT study which is very limited in Malaysia

\section{Results and Discussion}

The Concept of Muslim Friendly Tourism

Islamic tourism or Muslim friendly tourism (MFT) has gained the attention of many countries and stakeholders in the industry since the beginning of the introduction of the Shari'ah compliance hoteliers. MFT is one of the service industries that focuses on providing services in the tourism and hospitality sector that very much focuses on accommodation, food and beverages as well as travelling activities. All these services are shari'ah based with the objectives to indulge travellers who are demanding for the MFT services.

Religion and belief usually may influence the daily activities while travelling. In Islam, there are few surah in the al-Qur'an that encourage Muslims to travel and explore the world as well as to conserve the experience for the devotion of faith towards Allah SWT. There are nine verse in the alQur'an that encourage people to travel the world. The nine surah are as listed as follows: 
INTERNATIONAL JOURNAL OF ACADEMIC RESEARCH IN BUSINESS AND SOCIAL SCIENCES Vol. 8, No. 11, Nov, 2018, E-ISSN: 2222-6990 @ 2018 HRMARS

Table 1. Nine Surah in the al-Qur'an that encourage people to travel the world

\begin{tabular}{|l|l|c|}
\hline No. & \multicolumn{1}{|c|}{ Surah } & Verse Number \\
\hline 1 & Al-Mulk & 15 \\
\hline 2 & Muhammad & 10 \\
\hline 3 & Luqman & 31 \\
\hline 4 & Yusuf & 109 \\
\hline 5 & Ar-Rum & 42 \\
\hline 6 & Ali 'Imran & 137 \\
\hline 7 & Ar-Rum & 9 \\
\hline 8 & An-Naml & 69 \\
\hline 9 & Al-An'aam & 11 \\
\hline
\end{tabular}

These nine surah in the al-Qur'an portray the encouragement in Islam that human have the objective of travelling the world in order to find and analyse the history of the past. Ibn Battuta is one of the examples of Muslim scholar that travelled for approximately 30 years in the 14th century (Berkeley, 2018). The main reason that encourage Ibn Battuta to travel is because of the pilgrimage to Mecca to fulfil the fifth pillar of Islam but Ibn Battuta end up travelling 75,000 miles and visiting approximately 44 countries after he completed the pilgrimage to Mecca. From the Ibn Battuta story, it shows that religion do influence the travelling activities in one's life. According to Jafari and Scott (2014), religion influence and sculpt the choice of travelling especially the destination for discretionary purposes and the activities involve. Similarly, Zakaria and Abdul Talib (2010), found a comparable implication that claim travelling and touring are highly encourage in Islam and normally connected and interrelated with hospitality.

Based on previous study and literatures, the concept of Islamic tourism come earlier to the development of MFT. Few terms that describe traveling have been used in Islam. Baharom, Khalid and Yaakob (2010), clarify that the term of travelling nor tourism are divided into few terms that comprises of siyahah, ziarah, rehlah and umrah/hajj (pilgrimage). Siyahah means traveling of a person from one place to another for the purpose of tourism in order to entertain or explore new experiences (Sohirin \& Shah Jani, 2014). Meanwhile ziarah carry out the meaning of visiting others with a purpose and rehlah means to travel and pass by another place for a certain purpose. The word rehlah has been used specifically to travel for the purpose of education and commerce (Duman, 2011). In contrast, umrah/hajj is the travelling based on religion purposes that are different from the ordinary practice of common travelling or tourism activities. Umrah/hajj has been the main activities of Muslim yearly to visit Mecca and fulfil one of the 5 pillars in Islam.

Furthermore, Nor 'Ain Othman (2013) said that Islamic tourism can be defined from different areas according to the Islamic principles. The definition could be derived from the behaviour of the travellers including the motivation to travel, chosen destination as well as products and services offered that include accommodation, food and beverages and airlines. Nor 'Ain Othman (2013) define Islamic tourism as a sphere of interest or activity that is related to travel in exploring Islamic history, arts, culture and heritage and to experience the Islamic way of life. On the other perspective, Islamic 
tourism is defined by Islamic Tourism Centre (ITC) as Islamic Tourism is defined as any activity, event and experience undertaken in a state of travel that is in accordance with Islam (ITC, 2016). The definition of Islamic tourism also involve activities of travelling to and staying in places outside their usual environment for certain period of time with the intention derive from Islamic motivations that exclude any activities that are remunerated from within the visited place (Dunman, 2011). As a faithbased need and services, Islamic tourism also known as halal friendly tourism or halal travel. Akyol and Kilinc (2014) emphasize that halal tourism comprise of different sector that are related to each other that include halal accommodations, halal transportation, halal food and beverages, halal tour packages and halal finance.

However, the term Muslim friendly tourism emerged when the issue of 11/9 and Islamophobia begin worldwide. Many countries, Muslim and non-Muslim countries aspire to tap this niche segment in the tourism industry, but fail to mutually agreed on one common term that can represent the Islamic tourism industry. Japan, South Korea, Taiwan and recently accepted China are using the term halal tourism or halal travel in promoting their tourism market to the Muslaim travellers. Whereas country like Malaysia, Indonesia, Brunei and the GCC country also do not success in making the term apparent to the world. Thus, Malaysia initiate the term Muslim Friendly not only to cater the need of Muslim traveller but also to offer the same products and services that everyone including the nonMuslim to experience it too. According to Battour (2016):

"The term Muslim-friendly in tourism industry denotes an attempt to make the tourism experience enjoyable to observant Muslims. As such it is almost akin to the concept of 'Halal Tourism' but in a wider context to include allowing Muslims to perform religious duties. In other words, Muslim-friendly destinations not only offer plenty of 'Halal' services (such as Halal food and beverages, sex-segregated swimming pools, etc) but also comfortable places for Muslims to perform their daily prayers".

Cresent Rating (2016) outline the understanding of the MFT terms to provide an overview of the term that is domineering for all travel related stakeholders that are looking for the growth of the MFT market. MFT services (Cresent Ratin, 2016) include:

"The service or the facility has taken into account some faith-based needs of Muslim travellers. Although Halal-friendly facility/service may also convey the same meaning, the term Muslim friendly service/facility is more appropriate".

As a result, it can be surmised that the concept of MFT is based on the Islamic tourism concept but the term used has been accustom to fit the new segment of the tourism and hospitality industry to cater the need of travellers around the world and not leaving the religion based belief and practice to obstruct it. In short, Battour (2016) disclosed that MFT is an endeavour to turn tourism experience as a pleasure to Muslim travellers and letting them to perform their religious duties while travelling.

\section{The Malaysia Experience}

Over the past few years, tourism activity has shown substantial and sustained growth in terms of both the number of tourists and tourism receipts for Malaysia. Tourist arrivals in Malaysia is reaching almost 25.95 billion in 2017 which contribute to RM82.1 billion in the tourism receipts (Tourism Malaysia, 2018). Recently, in the recent survey by Dinar Standard, Malaysia is named as one of the world's favourite tourism destination whereas in the Halal travel indicator, Thomson Reuters (2016) 
INTERNATIONAL JOURNAL OF ACADEMIC RESEARCH IN BUSINESS AND SOCIAL SCIENCES Vol. 8, No. 11, Nov, 2018, E-ISSN: 2222-6990 @ 2018 HRMARS

declared Malaysia as one of the countries that have best developed ecosystem for Halal travel. Malaysia is the most culturally significant country with different races and ethnics living under one roof with its own unique culture.

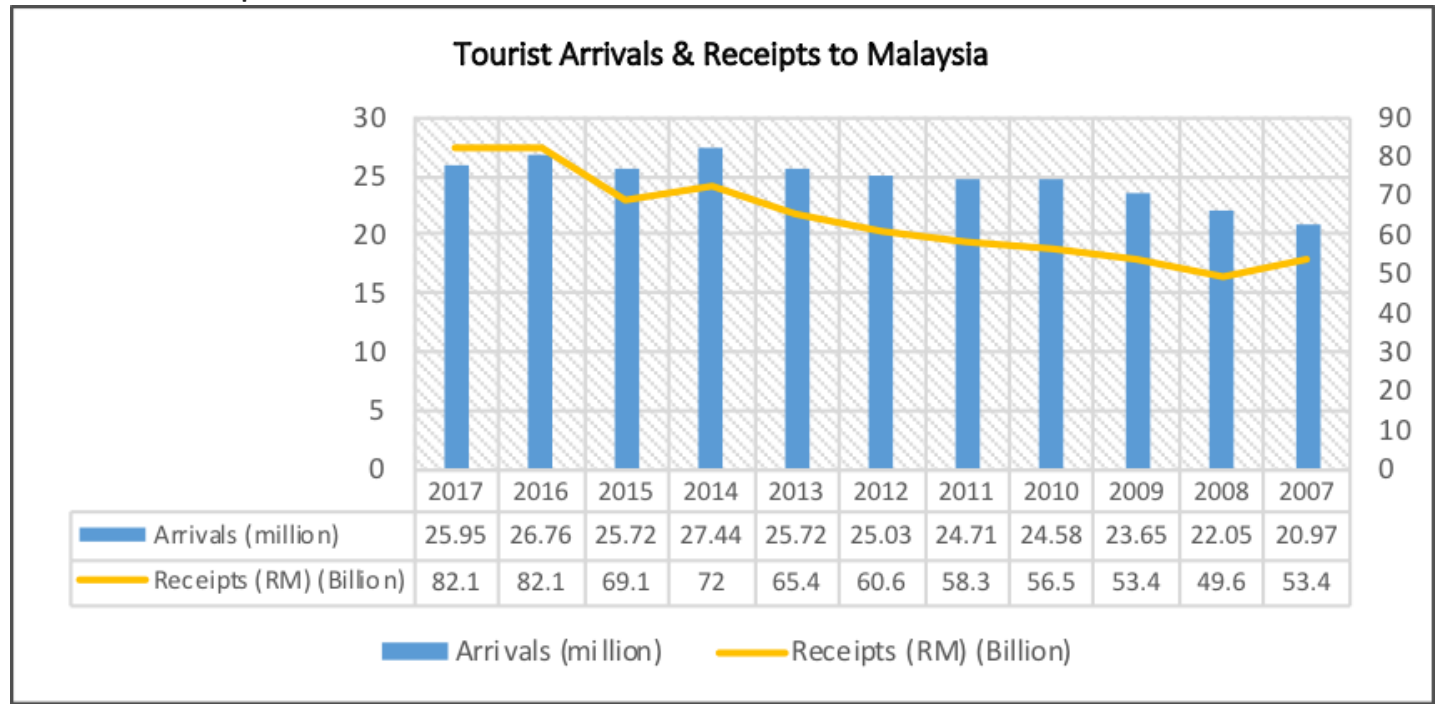

Source: Tourism Malaysia, 2018

This escalation growth pattern in the tourism industry has established Malaysia to become the major player in MFT to offer the best products and services for both Muslim and non-Muslim travellers. More achievement can be seen as stated in the Global Muslim Travel Index (GTMI) 2018, Malaysia continues to top the index for the eighth consecutive year. Malaysia has managed to maintain its leadership as one of the best destinations for Muslim travellers in terms of the various criteria that were analysed in GTMi 2018. The forecast of the demand for MFT services will continue to expand with incredible growth aligned with the evolving population of the world Muslim population around the world is estimated to escalate to 2.2 billion in the next 10 years to come (UNWTO, 2016). Due to this, the Muslim travel market is expected to endure a fast-paces growth to reached USD220 billion and increase up to USD300 billion by 2036 (GTMI, 2018).

The positioning of Malaysia as the pioneer in promoting Muslim friendly tourism foresee to transform Malaysia into a high-income nation by 2020 to achieve the target to become the leading tourist destination. It also will heighten the target of 36 million tourist arrivals and RM168 billion in receipts to intensify the existing Islamic tourism sector for the desirable economic benefits. Based on the tourist arrivals and receipts to Malaysia since 2007, Malaysia has shown a consistency in the tourism industry growth rate. Government of Malaysia has made significant efforts to ensure that tourism and hospitality plays a vital role to the economy. Tourism Malaysia has been extensively promoting the campaign 'Visit Malaysia' in 2014. Due to the intense promotions by the government, Malaysia has successfully attracted and build assurance to Muslim travellers to visit Malaysia.

Henderson (2003) indicate that tourism brings an extensive revenue for government especially in developing the industry in term of the positive economic consequences. The government of Malaysia has identified the tourism and hospitality industry as one of the sectors that plays a significant role in the economy and social development of Malaysia (Nor' Ain Othman, 2013). Since 
then, the government has played a vital role in the development of MFT in Malaysia. ITC was established in 2009 to aid the Ministry in undertaking strategic tourism research and market intelligence as well as providing training and capacity-building services in relation to Islamic tourism (ITC, 2016). ITC act as a government agency to foster and enrich the MFT in Malaysia.

Malaysia continues to lead the Global Islamic Economy Indicator, that were followed by the UAE and Saudi Arabia (GIE, 2017). Malaysia tourism industry is at the peak of its growth and widespread recognition, the acceptance of the MFT concept used by Malaysia tourism industry received a positive recognition and respond from tourists' in Malaysia. Muslim friendly Malaysia offers a widespread assortment of products and services for both Muslims and non-Muslims to experience including the facilities, halal food and beverages as well as Muslim friendly accommodation. It can be found that Malaysia has numerous and reachable halal products and services that perfectly accommodate all travellers to discover and experience the uniqueness of Malaysia. For instances, mosques and mushollas can easily be found in every district, as well as ample prayer rooms at almost every public place. Most food and beverages outlets serve JAKIM-certified halal food and many hoteliers provide Qibla direction and prayer mats in their guest rooms (ITC, 2016).

\section{Conclusion}

From the success story of Malaysia's experience in promoting the MFT, hurdle come and go towards the challenges in developing and establishing MFT to make it visible to the world. Some of the challenges of the MFT in Malaysia are technological advancement, economy development and people and organization.

Technological advancement contributes to the greater challenges in the development of MFT. In the Industrial Revolution 4.0 (IR4.0) era nowadays, the tourism industry needs to transform itself to be up in the scale of the usage of big data and the internet. Social media, online and transparent information and technology are needed to modernize the services in MFT. This undeniable technological innovations and changes can help in improving the services provided especially in the three main areas in the tourism industry such as hospitality services, accommodation services and F\&B services. Among the challenges in MFT is how to disseminate the promotion and create the awareness on MFT to all travelers around the world. In order to keep up this fast-changing industry, an interactives medium such as online application has been developed to enable the process and preparation of travelers much easier. Wang and Wang (2009) identify that technological issues that involve tourism activities usually encompass of interactive reservation systems, guest-room innovations, data mining, yield management.

The second challenge to MFT development is the accessibility towards the sustainable development management. The universal demand for sustainability has pushed most of Malaysia MFT stakeholders to practice the Muslim and environment friendly in delivering its services. In the case of Malaysia, ITC is seen as an Islamic hospitality and tourism expert pertaining to any references among stakeholders and industry players. ITC undertake a strategic research for tourism industry that enhance the MFT with the introduction of the Muslim friendly hospitality services standard in 2015 'MS2610:2015 - Muslim Friendly Hospitality Services - Requirements' that was initiated and led by International Institute for Halal Research \& Training (INHART) of International Islamic University Malaysia (IIUM). Prior to that, Malaysia has published no less than ten Malaysian Standards (MS) 
INTERNATIONAL JOURNAL OF ACADEMIC RESEARCH IN BUSINESS AND SOCIAL SCIENCES Vol. 8, No. 11, Nov, 2018, E-ISSN: 2222-6990 @ 2018 HRMARS

which are used as a guideline not only nationwide but also globally. The MS2610:2015 is focusing on 3 main areas of Dalil Siyahi (Tourist Guide), Dhiyafah (Accomodation) and Safar and Siyahah (Travel and Tour).

In the economy development, such issues of dependence upon the nation's economy, integration and globalization also plays an important challenge in MFT. Since the tourism industry the one of the largest contributors to the nation Gross Domestic Product (GDP), it is important for the government to fix all the issues and overcome the challenges towards MFT. The most common challenges in MFT are the people and organization. MFT has pushed Malaysian hotels to practice environment friendly in delivering services.

\section{ACKNOWLEDGEMENT}

This article is presented at The Seberang Prai International Conference on Ecotourism and Conservation Efforts 2018 (SPICEC 2018)

\section{References}

Al-Hamarneh, A., \& Steiner, C. (2004). Islamic tourism: Rethinking the strategies of tourism development in the Arab world after September 11, 2001. Comparative Studies of South Asia, Africa and the Middle East, 24(1), 173-182.

Battour, M. (2016). Halal Tourism or Muslim-Friendly Tourism. Assessed from https://www.crescentrating.com/magazine/opinion/3925/halal-tourism-or-muslim-friendlytourism.html

Battour, M., \& Ismail, M.N., Halal tourism: Concepts, practises, challenges and future, Tourism Management Perspectives (2015), http://dx.doi.org/10.1016/j.tmp.2015.12.008

Jafari, J., \& Scott, N. (2014). Muslim world and its tourisms. Annals of Tourism Research, 44(0), 1-19.

Zakaria, N. \& Abdul Talib, A. N. 2010, 'Applying Islamic market-oriented cultural model to sensitize strategies towards global customers, competitors, and environment', Journal of Islamic Marketing, vol. 1, no. 1, pp. 51-62.

Bekerly, UC. (2018). The Travels of Ibn Battuta, Berkerly Orias, Universiti of Carlifornia, assessed from https://orias.berkeley.edu/resources-teachers/travels-ibn-battuta

Duman, T. (2011). value of islamic tourism offering: Perspectives from the Turkish experience. Paper presented at World Islamic Tourism Forum (WITF, 2011), Kuala Lumpur, Malaysia.

Sohirin, M. S., \& Shah Jani, M. (2014). Tourism In Muslim Theology: A Study On Discourse And Objective. Paper presented at International Conference on Innovative Trends in Multidisciplinary Academic Research October 20-21, 2014. Istanbul, Turkey.

Othman, N. (2013). Islamic Tourism, Presented at the World Islamic Tourism Mart , 7th INCOMTHU Conference, Shah Alam, Malaysia

Bahrom, H., Khalid, M. M. and Yaakob,M. A. Z. (2010) "Pelancongan dari Perspektif Islam : Analisis Pendekatan Fiqh", Prosiding Seminar Pengurusan Hotel dan Pelancongan Islam, Universiti Institut Teknologi Mara (UITM) Shah Alam, 22-23 Jun 2010, p. 1-17.

Tourism Malaysia. (2018). Malaysia Tourism Statistics in Brief. Retrieved from http://www.tourism.gov.my/.

Tourism Malaysia. (2018). Retrieved from http://www.tourism.gov.my/. 
INTERNATIONAL JOURNAL OF ACADEMIC RESEARCH IN BUSINESS AND SOCIAL SCIENCES

Vol. 8, No. 11, Nov, 2018, E-ISSN: 2222-6990 C 2018 HRMARS

Malaysian Standard MS1900:1025, (2015). Muslim Friendly Hospitality Services-Requirements. Copyright 2015. Department of Standards Malaysia

Islamic Tourism Centre. (2016). Muslim Friendly Malaysia. Retrieved from http://www.itc.gov.my/resources/publications

Henderson, J. C. (2003). Managing Tourism and Islam in Peninsular Malaysia. Tourism Management, 24(4), 447-456.

Cresent rating, (2018). Global Muslim Islamic Economy report 2017/18 Travel Index 2018 (GTMI2018), assessed from www.crescentrating.com

Thomson Reuters (2017) Global Islamic Economy report 2017/18 (GIE), assessed from https://www.thomsonreuters.com/en. 